\title{
A magyar megyék szerepe és pozíciója a kutatási együittmüködési hálózatokban
}

\section{The role and the position of the Hungarian counties in research collaboration networks}

\author{
BRAUN ERIK, ILOSKICS ZITA, SEBESTYÉN TAMÁS
}

\begin{abstract}
BRAUN Erik: tudományos segédmunkatárs, ELKH, Közgazdaság- és Regionális Tudományi Kutatóközpont, Regionális Kutatások Intézete; 7621 Pécs, Papnövelde utca 22.; tudományos segédmunkatárs; Pécsi Tudományegyetem, Közgazdaságtudományi Kar; 7622 Pécs, Rákóczi út 80.; braun.erik@krtk.hu; https://orcid.org/0000-0001-7359-6018 ILOSKICS Zita: tudományos segédmunkatárs; ELKH, Közgazdaság- és Regionális Tudományi Kutatóközpont, Regionális Kutatások Intézete; 7621 Pécs, Papnövelde utca 22.; tudományos segédmunkatárs, Pécsi Tudományegyetem, Közgazdaságtudományi Kar; 7622 Pécs, Rákóczi út 80.; iloskics.zita@ktk.pte.hu; https://orcid.org/0000-0003-4776-1029 SEBESTYÉN Tamás: tudományos munkatárs, MTA-PTE Innovációs és Gazdasági Növekedés Kutatócsoport; 7622 Pécs, Rákóczi út 80.; egyetemi docens, Pécsi Tudományegyetem, Közgazdaságtudományi Kar; 7622 Pécs, Rákóczi út 80.; sebestyent@ktk.pte.hu; https://orcid.org/0000-0002-5596-0151
\end{abstract}

KULCSSZAVAK: tudásáramlás; innováció; regionális együttműködések; hálózatelemzés; többrétegű hálózat

ABSZTRAKT: A tanulmányban a magyar megyék (NUTS 3 szintű régiók) kutatási együttműködési kapcsolatait vizsgáljuk az Európai Unió által finanszírozott három keretprogram projektjeiben való részvételük alapján. A régiók közötti együttműködési kapcsolatokat többrétegü (multi-layer) hálózat segítségével térképezzük fel az egyes intézménytípusok (vállalatok, felsőoktatási intézmények, kormányzati intézmények, kutatóintézetek) közötti sajátosságok feltárása érdekében. Arra a kérdésre keressük a választ, hogy a magyar megyék hány együttmüködési kapcsolatot alakítottak ki a különböző dimenziók mentén, valamint milyen arányban létesítettek kapcsolatot a vizsgált európai régiókkal. A vizsgálatok során bemutatjuk továbbá, hogy a projektek alapján kialakult együttműködési hálózatban a különböző intézménytípusok szerepe az információáramlás szempontjából jelentősen eltérő az egyes megyékben. Az empirikus eredmények azt mutatják, hogy az együttműködési kapcsolatok száma Budapesten kiemelkedően magas, ami az intézmények koncentrált jelenlétének is köszönhető a régióban. A különböző intézménytípusok közötti kapcsolatok vizsgálata rávilágít a felsőoktatási intézmények és a kutatóintézetek tudományos együttműködések során betöltött fontos szerepére (Baranya megye és Hajdú-Bihar megye, illetve Győr-Moson-Sopron megye és Csongrád-Csanád megye). Végül az elemzésben rávilágítunk arra, hogy néhány régió (Heves megye, Nógrád megye, Tolna megye, Jász-Nagykun-Szolnok megye, Szabolcs-Szatmár-Bereg megye) kevésbé alakított ki együttműködési kapcsolatokat.

Erik BRAUN: research assistant, Institute for Regional Studies, Centre for Economic and Regional Studies, ELRN; Papnövelde utca 22., H-7621 Pécs, Hungary; research assistant, Faculty of Business and Economics University of Pécs; Rákóczi út 80., H-7622 Pécs, Hungary; braun.erik@krtk.hu; https://orcid.org/0000-0001-7359-6018 
Zita ILOSKICS: research assistant, Institute for Regional Studies, Centre for Economic and Regional Studies, ELRN; Papnövelde utca 22., H-7621 Pécs, Hungary; research assistant, Faculty of Business and Economics, University of Pécs; Rákóczi út. 80., H-7622 Pécs, Hungary; iloskics.zita@ktk.pte.hu; https://orcid.org/0000-0003-4776-1029

Tamás SEBESTYÉN: research fellow, MTA-PTE Innovation and Economic Growth Research Group; Rákóczi út 80., H-7622 Pécs, Hungary; associate professor, Faculty of Business and Economics, University of Pécs; Rákóczi út 80., H-7622 Pécs, Hungary; sebestyent@ktk.pte.hu; https://orcid.org/0000-0002-5596-0151

KEYWORDS: knowledge spillovers; innovation; regional collaborations; network analysis; multilayer networks

ABSTRACT: The main drivers of long-term economic growth are technological progress and innovation, which are increasingly built on collaborative relationships embedded in knowledge networks. However, such cooperation manifests through different channels and across different types of institutions. In this study, we examine the research cooperation links of the Hungarian NUTS 3 regions (counties) based on their participation in the projects of three Framework Programs (1999-2017) financed by the European Union. We map the cooperation links between the regions with the help of a multi-layer network in order to explore the specificities between the different types of institutions (companies, higher education institutions, government institutions, research institutions). Data on framework program collaboration is extracted from the Cordis dataset and inter-regional links are defined on this basis as joint participation in a given funded research project. This way we can proxy knowledge spillovers across institutions which are participants in these projects. The knowledge network built from these inter-regional links is then examined using network analytic tools in order to explore the structure of the complex cooperation links in more depth. The primary focus of the paper is to differentiate between the network connections (dimensions) observed across different types of institutions. In addition to the number of cooperation links of the Hungarian regions along each dimension (institution-type pairs), we also examine the density of cooperation (proportion of observed collaborative connections relative to all possible relations). Moreover, we measure the average distance of the regions in network terms, i.e. the number of links through which knowledge can be accessed by a given region.

The results of the network analysis show that the role of different types of institutions in the cooperation network differs significantly in every region in terms of the flow of information. Moreover, the number of cooperation links in Budapest is outstandingly high, and these connections have been built across a wide range of European regions. But the high number of connections in Budapest and Pest county is also due to the concentrated presence of institutions in the region. Two important conclusions can be drawn from the results. First, different types of institutions play different roles in knowledge spillover. In Veszprém county and Borsod-AbaújZemplén county, companies play a prominent role, while in Baranya county, higher education institutions, in Csongrád-Csanád county, research institutions and in Bács-Kiskun county, government institutions are the main sources of the interregional knowledge spillover. The analysis also highlights the important role of scientific co-operation in higher education institutions and research institutes (Baranya, Hajdú-Bihar, Györ-Moson-Sopron, and Csongrád-Csanád). Finally, we point out that some regions (Heves, Nógrád, Tolna, Jász-Nagykun-Szolnok, Szabolcs-SzatmárBereg) have developed less cooperative relations and less access to knowledge.

\section{Bevezetés}

A gazdasági növekedés forrását és a lemaradó országok, régiók felzárkózásának útjait hosszú ideje kutatják a közgazdászok, azonban az utóbbi két-három évtizedben konszenzus alakult ki abban a tekintetben, hogy a hosszú távú növekedés 
legfőbb hajtóereje a technológiai fejlődés és a tudás megszerzése, felhalmozása (lásd Solow 1957; Romer 1990; Grossman, Helpman 1991; Aghion, Howitt 1992). Ennek tükrében felmerül a kérdés, hogyan keletkezik az új tudás, és hogyan férhetnek hozzá a gazdaság szereplői a már meglévő tudáshoz. A vállalatok térbeli tömörüléséből származó előnyökkel kapcsolatban Marshall (1961) arra hívta fel a figyelmet, hogy a vállalatok és a dolgozók információkat és tudást osztanak meg egymással különböző csatornákon keresztül, amelynek következtében a térben koncentrálódott vállalatok között beindul az információ- és tudásáramlás, más néven spillover vagy túlcsordulási hatás. Az ezzel kapcsolatos empirikus kutatások arra az eredményre jutottak, hogy a más gazdasági szereplőktől származó információk és tudás a térben közelebb elhelyezkedő vállalatokra erősebb pozitív hatást fejt ki, mint a távolabbi vállalatokra (lásd Jaffe 1989; Feldman 1994; Anselin, Varga, Ács 1997).

Breschi és Lissoni (2003) azt hangsúlyozzák, hogy a térbeli közelség hozzájárul a társadalmi kapcsolatok létrejöttéhez és a gazdasági szereplők közötti bizalom kialakulásához. A térbeli közelségből fakadó előnyök csak abban az esetben érvényesülnek, ha a szereplők kapcsolatba is lépnek egymással, és nem elszigetelten, önállóan müködnek. Ezt támasztja alá, hogy azon vállalatok, amelyek gyakrabban alakítottak ki lokális kapcsolatokat, magasabb innovációs teljesítmény értek el (Breschi, Lissoni 2003; Boschma, ter Wal 2007). Eszerint különbséget kell tenni a földrajzi közelség és a gazdasági szereplőkkel kialakított kapcsolatok között, tehát a földrajzi távolság mellett a közelség más dimenziójú megközelítésére is szükség van az innovációs folyamatok vizsgálatakor (Boschma 2005). Az új tudás létrehozása és végső soron az innováció alapvetően együttműködési folyamat, ezért az innovatív tevékenységeket tekintve fontos szereppel bírnak a gazdasági szereplők közötti együttmúködési kapcsolatok (Lundvall 2010).

Broekel és Meder (2008), valamint Lobo és Strumsky (2008) vizsgálatai azonban rámutatnak arra is, hogy a túl sok lokális kapcsolat negatív hatást is gyakorolhat az innovációs tevékenységre, ugyanis ezekben az esetekben ugyanaz az információ és tudás kering körbe-körbe a szereplők között. Ezzel szemben több empirikus elemzés is a régión kívüli kapcsolatok innovációs teljesítményre gyakorolt pozitív hatását mutatta ki (Lobo, Strumsky 2008; Broekel, Brenner, Buerger 2015). Egy adott régió elsősorban úgy férhet hozzá információkhoz és új tudáshoz, hogy a régióban tevékenykedő szereplők a régión kívüli kapcsolataik által behozzák azokat, majd a lokális kapcsolatokon keresztül szétszórják a helyi szereplők között (Breschi, Lenzi 2016). Santoalha (2018) hangsúlyozza, hogy a sikeres innovációs rendszer lokálisan (régión belül) és globálisan (régión kívül) kiegyensúlyozott kapcsolatokkal rendelkezik, valamint Fitjar és Rodriquez-Pose (2020) szerint is a lokális és a globális együttműködések egyaránt pozitív befolyással bírnak a vállalatok innovációs tevékenységére.

A regionális innovációhoz kapcsolódó kutatások az együttmúködéseket különböző intézménytípusok között vizsgálják, mint például vállalatok, egyetemek, 
kutatóintézetek, kormányzati szervek vagy pénzügyi intézmények (lásd Becker, Dietz 2004; Csáfordi et al. 2018; D’Amrosio et al. 2019; Fritsch, Slavtchev 2010; Henderson 1997; Jacobs 1969; Sebestyén et al. 2021). A vállalkozói ökoszisztémát vizsgáló kutatások is azt mutatják, hogy a különböző szereplők közötti sürű interakciók támogatják az innovációs tevékenységeket (Ács et al. 2017; Alvedalen, Boschma 2017). A szereplők intézménytípus szerinti megkülönböztetése kapcsán kiemelt jelentőséggel bír a vállalatok és az egyetemek közötti kapcsolatok elemzése, amelyek erőteljesen képesek befolyásolni az innovációs teljesítményt (Reichert 2019). Azokban a régiókban, ahol egyetemek működnek, az innovációs aktivitás is erősebb (Schaeffer, Fischer, Queiroz 2018). A vállalatok innovációs tevékenységére szintén pozitív hatást gyakorolnak az egyetemekkel kialakított kapcsolatok (Maietta 2015). Fontos azonban megjegyezni, hogy az egyes régiók egyrészt eltérő mértékben alakítanak ki régión belüli és régión kívüli kapcsolatokat, másrészt a különböző intézménytípusok is eltérő intenzitással alakítanak ki kapcsolatokat más intézményekkel. Az európai régiókat vizsgálva az látható, hogy a régiók egy jelentős csoportja elsősorban a felsőoktatási intézmények és a kutatóintézetek által szerez információt és tudást a régión kívülről (Sebestyén et al. 2021).

Összességében tehát megállapítható, hogy a különböző intézménytípusokkal kialakított kapcsolatrendszerek az új információkhoz való hozzáférésén és fóként a tudás felhalmozásán keresztül serkentőleg hatnak az innovációs tevékenységre, végső soron a gazdasági növekedésre (1. ábra).

A földrajzi közelség mellett tehát fontos tényező a gazdasági szereplők különféle intézménytípusokkal kialakított kapcsolatrendszere, azonban felmerül a

1. ábra: A különböző intézménytípusokkal kialakított kapcsolatok

gazdasági növekedésre gyakorolt hatásmechanizmusa

The impact of links with different types of institutions on economic growth

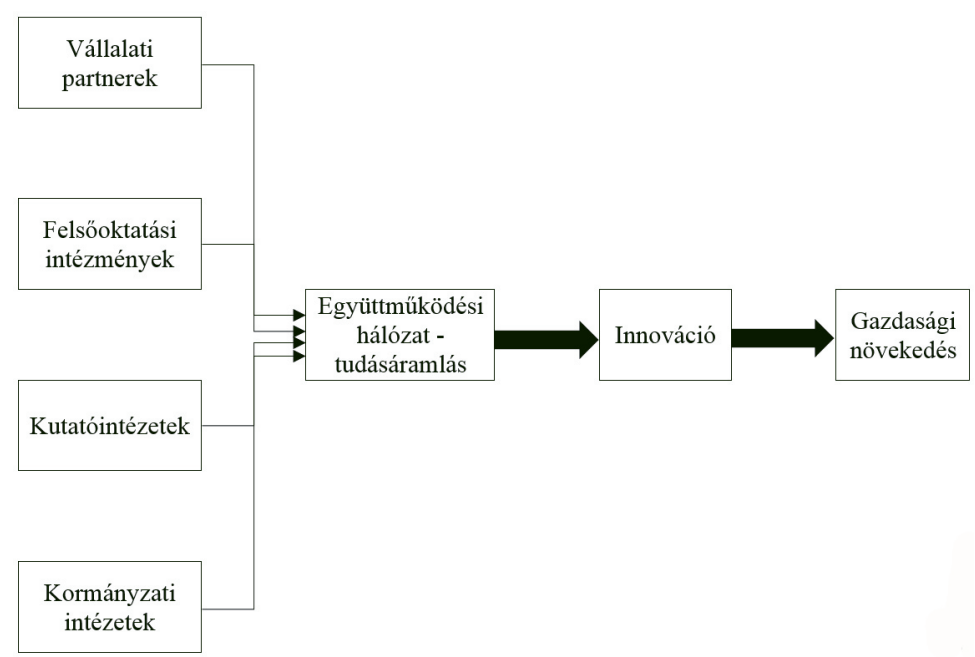

Forrás: saját szerkesztés 
kérdés, hogy miként értelmezhetők ezek az együttműködési kapcsolatok. Az együttműködési kapcsolatok meghatározására alkalmazott egyik módszer a szabadalmi bejelentéseken alapul (lásd például Sebestyén, Varga 2013). Ebben az esetben két szereplő között akkor tételezzük fel az együttműködési kapcsolatot, ha közösen jelentettek be egy szabadalmat, hiszen ekkor nagy valószínűséggel közösen is dolgoztak rajta. Egy másik gyakran alkalmazott módszer szerint az együttműködések azonosítása az Európai Unió finanszírozási Keretprogramjai (KP) keretében történő közös kutatási projektben való részvétel alapján történik (lásd Akçomak, Erdil, Çentinkaya 2018; Varga, Sebestyén 2015). Ha a program keretein belül közös kutatási projektben vesz részt két intézmény, akkor együttmüködési kapcsolatot tételezünk fel közöttük. Mindkét esetben a szereplőket a földrajzi elhelyezkedésük alapján hozzákötjük az egyes régiókhoz, ezzel megjelenítve az egyes régiók között kialakuló kapcsolatrendszereket.

Ebben a tanulmányban a KP-k keretei között megvalósult projektek alapján határozzuk meg az egyes régiók kapcsolatrendszereit a különböző intézményi dimenziók mentén. A KP-adatok használatát az motiválja, hogy a programok által megvalósult kutatási együttműködések segítik a lemaradó régiók innovációs felzárkózását a határokon átívelő kapcsolatok kialakításával (Reillon 2017), valamint a keretprogram-hálózatokból kinyert tudás fokozza az innovációs tevékenységet, különösen a kelet-közép-európai régiók esetében (Varga, Sebestyén 2015). Ezen alapulva érdemesnek tartjuk megvizsgálni, hogy a különböző intézményi dimenziókban a magyar régiók milyen kapcsolatrendszerrel bírnak, mennyire képzik az együttműködési hálózat szerves részét, és milyen különbségek figyelhetők meg a magyar régiók között.

A hazai szakirodalomban számos alkalommal foglalkoztak a KP-okban való részvétellel és az együttmúködések szerkezetének, valamint a kapcsolatok gazdasági teljesítményre gyakorolt hatásának elemzésével (Hau, Sebestyén, Varga 2016; Kosztyán, Csányi, Kurbucz 2019; Sebestyén 2011; Sebestyén 2012; Varga, Sebestyén 2015). Tanulmányunk újszerüsége abban rejlik, hogy az általunk elvégzett vizsgálatok a KP-ok szélesebb körére (5., 6. és 7. KP) terjednek ki, továbbá a régiók közötti kapcsolatokat különféle intézménytípusok (vállalatok, felsőoktatási intézmények, kormányzati intézetek, kutatóintézetek) szerint vizsgáljuk meg. Adott két régió között tehát a kapcsolat erőssége attól is függ, hogy melyik csatornát vizsgáljuk. Előfordulhat, hogy például két régió felsőoktatási intézményei több közös projektekben is részt vesznek, azonban a vállalataik elszigetelten müködnek egymástól. Ebben az esetben a felsőoktatási intézmények közötti együttmüködés szoros, míg a vállalatok között alacsony intenzitású. Végül, a régiók közötti kapcsolatok az egyik régióhoz tartozó vállalatok és a másik régióhoz tartozó felsőoktatási intézmények alapján is meghatározható, ami újabb két dimenzió mentén írja le a két régió között kialakult együttmüködések intenzitását. Annak érdekében, hogy a magyar régiók különböző típusú együttműködéseit, és ezáltal a tudásáramlás különféle csatornáit feltérképezzük, többrétegű (multilayer) 
hálózatelemzési módszert alkalmazunk, ahol a hálózat csúcsait a régiók, éleit a régiók közötti együttműködési kapcsolatok, míg a „rétegeket” az intézménytípusok alapján határozzuk meg.

A régiók közötti kapcsolatok tehát a közös kutatási együttmúködések szerint kerülnek meghatározásra, amelyek alkalmasak a tudásáramlás mérésére. Az így létrejött tudáshálózatot ezt követően hálózatelemzési eszközök segítségével vizsgáljuk meg. A hálózati közelítés kifejezett előnye, hogy a hálózati kapcsolatok tágabb szerveződési mintázataira is képes reflektálni, így segítségével mélyebben feltárható a tudáskapcsolatok rendszere, mintha a közvetlen kapcsolódásokra fókuszálva pusztán az együttműködések számát vizsgálnánk különböző metszetekben. Erre mutatnak példát a tanulmányban alkalmazott hálózati távolság alapú számítások is, amelyek feltárják, hogy egy adott régió milyen típusú intézményein keresztül képes a legrövidebb módon tudáshoz jutni a többi régiótól.

A tanulmány felépítése a következő. A bevezetést követően részletesen ismertetjük a felhasznált adatbázist, valamint betekintést nyújtunk abba, hogyan építhető fel az általunk használt többdimenziós hálózat az együttmüködési projektek alapján. A harmadik fejezetben bemutatjuk, hogy milyen hálózati mutatók segítségével vizsgáljuk meg a magyar régiók együttműködési hálózatban betöltött szerepét és pozícióját, majd ennek megfelelően a negyedik fejezetben a magyar régiókra kapott empirikus eredményeket ismertetjük. Végül a tanulmányt az eredmények összefoglalásával és a következtetésekkel zárjuk.

\section{A felhasznált adatbázis és a többdimenziós hálózat bemutatása}

Mielőtt részletesen ismertetnénk az alkalmazott hálózatelemzési módszereket és a magyar régiók KP-okban kialakított kapcsolatrendszerét, elöször röviden betekintést nyújtunk az általunk felhasznált adatbázisba, majd ezt követően egy példán keresztül bemutatjuk a többrétegű hálózat legfőbb jellemzőit, illetve felvázoljuk, hogyan hozható létre egy ilyen hálózat a felhasznált adatokból.

\section{Adatok}

A régiók közötti együttműködési kapcsolatokat az EU által finanszírozott három KP (1999-2017) adatai alapján határoztuk meg a Cordis adatbázis felhasználásával. Az adatbázisban a projektben résztvevő intézmények és a projektek egyedi szerződésszámai alapján projektrésztvevő párokat azonosíthatunk. A dolgozatban a globális (régiók közötti) kapcsolatokra fókuszálunk, ezért az intézmények területi (NUTS 3) besorolása szükséges. Az adatbázis által biztosított területi besorolás, valamint az intézmények azonosító számai azonban hiányosak, több esetben korrekcióra szorultak. A NUTS 3-as szintű régióknak Magyarországon a megyei szint felel meg, így a tanulmány empirikus elemzésében a megye megnevezést 
használjuk a hazai régiók kapcsán, amely alatt a 19 megyét és az önálló, fóvárosi NUTS 3-as szintű régiót értjük. A nem hazai NUTS 3-as területi egységekre való utaláskor megtartjuk a régió kifejezést.

Az intézményeket új azonosítóval láttuk el, és a regionális osztályozás pontosítása érdekében elvégeztük teljes területi átsorolásukat az elérhető helyadatok alapján. Az intézmények neve, területi besorolása és címe alapján egy karakterlánc mintaillesztési (string matching) algoritmus segítségével feltártuk az intézménypárok hasonlóságait. Ugyanezt az eljárást manuálisan is elvégeztük az intézmények egy részmintáján és összevetettük az algoritmus eredményével. Amennyiben az intézménypárok hasonlósági értéke nem haladta meg az alsó küszöbértéket, akkor különbözőnek, ellenkező esetben azonosnak tekintettük őket. A két küszöbérték közötti tartományba eső párokat manuálisan ellenőriztük, majd egyedi azonosítóval láttuk el. A megtisztított adatbázisban rendelkezésünkre állnak az adatok minden finanszírozott projektről, a projekt időtartamáról, a résztvevők NUTS 3 szintű helyéről és intézménytípusáról (vállalat, felsőoktatási intézmény, kormányzati intézet, kutatóintézet).

\section{Többrétegü hálózat meghatározása}

Annak érdekében, hogy az intézménytípusok alapján több együttműködési csatornát is megvizsgáljunk, többrétegü hálózatot hoztunk létre. A módszertan a teljes hálózatot jellemző heterogén kapcsolatokat modellezi ugyanazon szereplők részvételével, de különböző rétegeken keresztül (Interdonato et al. 2020). A többrétegü hálózatok szerepét széleskörű szakirodalom vizsgálja. Porter (2018) bemutatja, hogy a legtöbb valós hálózat, például az emberek közötti kommunikáció, a közlekedési hálózatok, de az együttműködési hálózatok kapcsolatai is több csatornán határozhatók meg. Boccaletti és szerzőtársai (2014) összegzik a módszer széleskörü alkalmazási lehetőségét, a társadalmi, a technológiai és a gazdasági rendszerek vizsgálatában.

A többrétegű hálózatok mélyebb megértését szolgálja a 2. ábrán látható példa. A mintahálózatunkat három régió (R1, R2 és R3) alkotja, ahol a régiók a hozzájuk tartozó intézmények együttműködései alapján állnak egymással kapcsolatban, méghozzá aszerint, hogy vállalatokról $\left(\alpha_{1}\right)$ vagy kutatóintézetekről $\left(\alpha_{2}\right)$ van-e szó. Ebben az esetben tehát az intézménytípusok jelölik a hálózat „rétegeit”. Fontos megjegyezni, hogy a régiók négy különböző dimenzióban kapcsolódhatnak össze egymással: (i) az egyik régió vállalatai a másik régió vállalataival, (ii) az egyik régió kutatóintézetei a másik régió kutatóintézeteivel, (iii) az egyik régió vállalatai a másik kutatóintézeteivel, valamint a (iv) az egyik régió kutatóintézetei a másik vállalataival. Az utolsó két eset között az okozza az eltérést, hogy különbséget teszünk, melyik régióhoz tartoznak a vállalatok és melyikhez a kutatóintézetek. A 2. ábra jobb oldalán látható mintahálózatban például az első régióhoz (R1) tartozó vállalatok együttmüködtek a második régió (R2) kutatóintézeteivel, azonban az első régió kutatóintézetei és a második régió vállalatai között nem létesült kapcsolat. 
2. ábra: Többrétegü hálózat szemléltetése The illustration of multilayer network

\begin{tabular}{l|ccc|}
\multicolumn{3}{c}{} & \multicolumn{1}{c}{$\alpha_{1}$} \\
\cline { 2 - 4 } R1 & 0 & 1 & 1 \\
R2 & 1 & 0 & 0 \\
R3 & 1 & 0 & 0 \\
\cline { 2 - 4 } & & & \\
R1 & 0 & 0 & 0 \\
R2 & 1 & 0 & 0 \\
R3 & 0 & 0 & 1 \\
\cline { 2 - 4 } & R1 & R2 & R3
\end{tabular}

\begin{tabular}{|lll|}
\multicolumn{1}{c}{} & $\alpha_{2}$ \\
\hline 0 & 1 & 0 \\
0 & 0 & 0 \\
0 & 0 & 1
\end{tabular}

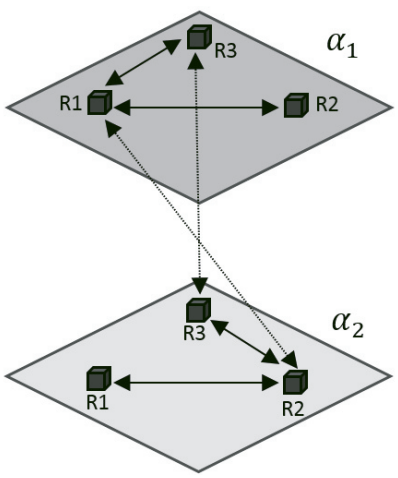

Forrás: saját szerkesztés

Az egyrétegű hálózatokhoz hasonlóan a többrétegü hálózatok esetében is felírható a kapcsolati mátrix, ami a 2. ábra bal oldalán látható. Ebben az esetben egy blokkmátrixról van szó, ami a két réteg miatt négy részből áll. A bal felső részmátrix első oszlopában és második sorában szereplő 1-es érték azt mutatja, hogy a második régióhoz tartozó vállalatok együttmúködtek az első régió vállalataival. A szóban forgó részmátrix fontos tulajdonsága, hogy szimmetrikus, azaz irányítatlan kapcsolatokról van szó. A bal alsó részmátrix első oszlopában és második sorában szereplő 1-es érték azt jelzi, hogy a második régió kutatóintézetei alakítottak ki kapcsolatot az első régió vállalataival. A blokkmátrix diagonális mátrixaitól eltérően ebben az esetben már nem szimmetrikus a részmátrix, azonban a jobb felső részmátrix első sorának második eleme is 1-es értéket vesz fel, megmutatva azt, hogy az első régió vállalatai is kapcsolatban állnak a második régió kutatóintézeteivel. Tehát a blokkmátrix összességében szimmetrikus, azonban a diagonálison kívül elhelyezkedő részmátrixok általános esetben nem azok.

Az általunk használt többrétegű hálózat meghatározásához először létrehozunk egy P projekt mátrixot, melynek sorai az intézményeket, oszlopai pedig a projekteket jelölik. A mátrix eleme abban az esetben lesz egy $\left(\mathrm{p}^{\mathrm{i}, \mathrm{k}}=1\right)$, ha az $i$ intézmény részt vett a $k$ projektben. Ekkor az A kapcsolati mátrix a következő egyszerű művelettel határozható meg: $\mathrm{A}=\mathrm{PP}^{\mathrm{T}}$, ahol $\mathrm{P}^{\mathrm{T}}$ a projekt mátrix transzponáltja. Az így kapott $A$ kapcsolati mátrix az intézménypárok közötti együttműködések gyakoriságát mutatja meg a közös projektekben való részvételek számossága alapján.

A felhasznált adatok 1999-2017 közötti periódust ölelnek fel, azaz tizenkilenc időszakra vonatkozóan határozhatók meg az intézménypárok közötti együttműködések. Az elemzésünk célja egy általános képet adni a magyar régiók KP-okban való részvételéről és kapcsolatrendszeréről, ezért a vizsgálatok során nem vizsgáljuk az együttműködések dinamikáját, hanem az intézménypáronkénti együttműködéseket átlagoljuk az idő szerint. Következésképpen előfordulhat olyan eset, amikor átlagosan egynél kisebb gyakorisággal működött együtt két intézmény. 
A következő lépésben az intézmények területi elhelyezkedése (NUTS 3 régió) és típusa (vállalat, felsőoktatási intézmény, kormányzati intézet, kutatóintézet) alapján kategorizálási vektorok felhasználásával egy háromdimenziós tömböt (W) hozunk létre, ahol a $\mathrm{d}^{\mathrm{T}}$ kategorizálási sorvektor az intézménytípusra, míg $\mathrm{d}^{\mathrm{R}}$ sorvektor a régióra utal:

$$
w_{r f i, q g j}=a_{l_{1} l_{2}} \mid d_{l_{1}}^{R}=r, d_{l_{2}}^{R}=q, d_{l_{1}}^{T}=f, d_{l_{2}}^{T}=g
$$

A tömb elemei ( $\left.\mathrm{w}_{\mathrm{rfi}, q g}\right)$ az $r$ régióban elhelyezkedő, ftípusú i intézmény és a $q$ régióhoz tartozó, g típusú j intézmény közötti együttműködés gyakoriságát mutatják, ahol $f, g=1,2, \ldots F$ az intézménytípusok, $r, q=1,2, \ldots R$ a régiók, az $i, j=1,2, \ldots I_{\mathrm{f}, \mathrm{r}}$ az intézmények indexe. Ezt követően a regionális szintű, intézménytípusok szerinti kapcsolati mátrixot $\left(\mathrm{W}^{\mathrm{f}, \mathrm{g}}\right)$ a régiókhoz tartozó, adott intézményi kategóriába tartozó intézmények kapcsolatainak összegzésével kapjuk meg:

$$
w_{r, q}^{f, g}=\sum_{i=1}^{I_{f, r}} \sum_{j=1}^{I_{f, r}} w_{r f i, q g j}
$$

Ekkor a $w_{r, q}^{f, g}$ azt mutatja meg, hogy az $r$ régióban elhelyezkedő $f$ típusú intézmények összesen hány közös projektben vettek részt a q régióhoz tartozó $g$ típusú intézményekkel. Fontos megjegyezni, hogy a kiinduló intézménypárok közötti együttműködéseket idő szerint átlagoltuk, következésképpen az együttműködések átlagos száma 0 és 1 közötti értéket is felvehet.

Az általunk felhasznált adatbázisban négy intézménytípust különböztetünk meg: (i) vállalatok $(f, g=1)$, (ii) felsőoktatási intézmények $(f, g=2)$, (iii) kormányzati intézetek $(f, g=3)$ és (iv) kutatóintézetek $(f, g=4)$. Ennek megfelelően az $f$ és a $g$ index négy-négy különböző értéket vehet fel, következésképpen tizenhat különböző kapcsolati mátrix és hálózat írható fel.

Az így kapott mátrixból létrehozható egy olyan többrétegű hálózat, amelyben a csúcsok az egyes régiók, a kapcsolatok az együttmüködések gyakoriságai, míg a rétegek (layers) az egyes intézménytípusok. Ebben az esetben a kapott $\mathrm{W}^{\mathrm{f}, \mathrm{g}}$ mátrixokból a 2. ábrához hasonlóan egy blokkmátrix $\left(\mathrm{W}^{\mathrm{B}}\right)$ hozható létre, amelyben az egyes blokkok (négy réteg esetén tizenhat különböző blokk) a régiók intézménytípusok szerinti kapcsolatait jelenítik meg. A blokkmátrix diagonális mátrixai a rétegen belüli kapcsolatokat írják le, másképpen fogalmazva a régiók azonos intézménytípusba tartozó szereplői közötti kapcsolatok gyakoriságát mutatják, míg a többi részmátrix az eltérő intézménytípusok alapján ismerteti a régiók összekapcsoltságát.

A régiók közötti kapcsolatokat úgy is meghatározhatjuk, hogy nem vesszük figyelembe a régióhoz tartozó intézmények közötti együttműködések gyakoriságát, és kizárólag arra koncentrálunk, hogy az adott dimenzió mentén adott két régióhoz tartozó intézmények között volt, vagy nem volt együttmúködés. Előbbi esetében két régió közötti kapcsolat értéke 1, míg utóbbinál 0. Ennek megfelelően a régiók közötti bináris kapcsolati mátrix $\left(B^{f, g}\right)$ elemei a következőképpen írhatók fel: 


$$
b_{r, q}^{f, g}=\left\{\begin{array}{l}
1, w_{r, q}^{f, g} \geq 0 \\
0, w_{r, q}^{f, g}=0
\end{array}\right.
$$

Ebben a fejezetben részletesen bemutattuk hogyan épül fel az empirikus elemzés során felhasznált többrétegű hálózat, amely a NUTS 3-as régiók közötti együttműködések gyakoriságát írja le a különböző intézménytípusok szerint. A következő részben a hálózat szerkezetét leíró mutatókat ismertetjük az egyes rétegek szerint.

\section{Az alkalmazott hálózatelemzési eszközök}

Ahogy az előző részben kifejtettük, a régiók közötti kapcsolatokat négy különböző réteg és ennek megfelelően összesen tizenhat különféle dimenzió szerint tudjuk megvizsgálni. Ezeket a különböző dimenziójú hálózatokat felhasználva egyrészt bemutatjuk, hogyan határozható meg, hogy a magyar régiók az egyes dimenziókban mennyi kapcsolatot alakítottak ki és milyen mértékben álltak kapcsolatban a többi régióval. A kapcsolatok számával választ kaphatunk arra, hogy milyen erősen áramlott az adott régióba a tudás, míg a sürüség azt mutatja meg, hogy a régiók hány százalékával sikerült kapcsolatot kialakítani, azaz a régiók hány százalékából sikerült tudáshoz jutni. Másrészt egy olyan módszertant is felvázolunk, amellyel megmérhető, hogy a régiók az egyes dimenziók mentén milyen hatékonyan voltak képesek tudást szerezni a többi régiótól.

\section{Kapcsolatok száma és sürüség}

Elsőként tehát azt mutatjuk be, hogyan határozható meg formálisan a régiók kapcsolatainak száma az egyes dimenziók mentén. Két régió kapcsolatának felírásakor figyelembe vesszük, hogy milyen intenzíven álltak kapcsolatban egymással, hiszen az intenzívebb kapcsolatok vélhetően nagyobb mennyiségü tudásáramlást is tettek lehetővé. Ebből kiindulva, a régiók $(\mathrm{kr}(\mathrm{f}, \mathrm{g}))$ súlyozott kapcsolatainak száma (súlyozott fokszáma) a következőképpen írható fel:

$$
k_{r}^{f, g}=\sum_{q=1}^{R} w_{r, q}^{f, g}
$$

Ahhoz, hogy a különböző dimenzióra vonatkozó súlyozott fokszámok összehasonlíthatók legyenek egymással, ezeket az értékeket az adott dimenzió legnagyobb értéke szerint normalizáljuk:

$$
\bar{k}_{r}^{f, g}=\frac{k_{r}^{f, g}}{\max _{r}\left(k_{r}^{f, g}\right)}
$$

Ebben az esetben tehát a normalizált súlyozott fokszám azt mutatja meg, hogy az adott régió összesen hány kapcsolatot alakított ki a legtöbb kapcsolatot kialakító régióhoz képest. Ha az r régió például azfg dimenzióban magas értékkel, 
míg a gf dimenzióban alacsony értékkel rendelkezik, akkor előbbi esetében relatív jobban, utóbbiban pedig relatív rosszabbul teljesített.

A másik fontos hálózatelemzési indikátor, a sürüség azt mutatja meg, hogy a régiók milyen arányban alakítottak ki kapcsolatokat a többi régióval, másképpen fogalmazva milyen sürü partneri körrel rendelkeznek. Fontos hangsúlyozni, hogy ebben az esetben nem a teljes hálózat sűrüségéről van szó, hanem arról, hogy egy adott régió az összes lehetséges partnere közül hánnyal alakított ki kapcsolatot. Ennek megfelelően az így definiált sürüség $s_{r}^{f, g}$ a következőképpen írható fel:

$$
S_{r}^{f, g}=\frac{\sum_{q=1}^{R} b_{r, q}^{f, g}}{R-1}
$$

Ha egy régió sűrüsége magas, akkor az adott dimenzióban magas arányban alakított ki kapcsolatokat a többi régióval. Mivel ennél a mutatónál a bináris hálózati kapcsolatok jelentik a kiindulási alapot, a kapott $s_{r}^{f, g}$ érték úgy is értelmezhetö, hogy az adott régió kapcsolatrendszere mennyire koncentrált (alacsony $s_{r}^{f, g}$ érték) vagy diverzifikált (magas $s_{r}^{f, g}$ érték).

\section{Domináns hálózat és az intézménytípusok szerepe}

A tudásáramlás szempontjából fontos tényező, hogy az egyes régiók milyen közel helyezkednek el egymáshoz, azonban ebben az esetben nem a földrajzi elhelyezkedés, hanem a kialakított kapcsolatrendszerben értelmezendő távolság a fontos. Ha egy régió egy másik régióval több projektben is együttműködik, akkor a közöttük lévő kapcsolat és a tudásáramlás is erős, ezáltal a kapcsolatrendszerben is közelebb helyezkednek el egymáshoz, mintha csak néhány közös projektben müködtek volna együtt. Tehát a gyakoribb együttmüködés a kapcsolatrendszeren belüli közelebbi elhelyezkedést jelzi. Ezek alapján formailag a következőképpen határozható meg két régió közötti (közvetlen) távolság $d_{r, q}^{f, g}$ :

$$
d_{r, q}^{f, g}=\frac{1}{w_{r, q}^{f, g}}
$$

További lényeges tulajdonság, hogy a régiók nemcsak közvetlenül, hanem közvetett módon, egy harmadik (vagy több másik) szereplőn keresztül is kapcsolatban állhatnak egymással. Így egy adott $A$ régióhoz azon régióktól is eljuthat az új tudás, amelyekkel nem működtek együtt közös projektben. Ha az A régió csak közvetett módon, egy harmadik $C$ régión keresztül áll kapcsolatban $B$-vel, akkor az $A$ és $B$ közötti távolság úgy határozható meg, hogy megnézzük, milyen távol van AC-től, majd ehhez hozzáadjuk $B C$-től vett távolságát is. Amennyiben csak több köztes régión keresztül áll kapcsolatban a két kiválasztott régió, úgy a közöttük lévő távolság is növekszik a köztes szereplők közötti távolságoknak megfelelően.

A közvetlen és a közvetett kapcsolatok alapján meghatározott távolságok felhasználásával megnézhetjük, hogy az egyes régiók átlagosan milyen távol vannak egymástól, megmérve ezzel a tudáshoz való hozzáférés átlagos erősségét. Fontos azonban megjegyezni, hogy egy régióból többféleképpen is eljuthatunk 
egy másik régióba, azaz több csatornán keresztül is hozzáférhetünk a másik régió tudásához. Emiatt a két régió közötti távolságot a legrövidebb távolság (legrövidebb út) alapján határozzuk meg, ami a tudásáramlás szempontjából hatékony. Nagy méretű hálózatoknál nagyszámú lehetséges út létezik két régió között, így a legrövidebb távolságok meghatározása jelentős számítási kapacitást igényel. A régiók közötti legrövidebb távolságokat az R szoftver iGraph csomagjának alkalmazásával határoztuk meg, amely a Dijkstra algoritmuson alapul (Dijkstra 1959). Az algoritmus egy olyan távolságmátrixot eredményez, ami megmutatja minden két régió közötti legrövidebb távolság hosszát. Előfordulhat olyan eset, hogy néhány régióhoz közvetlenül és közvetett módon sem lehet eljutni, ekkor a távolság végtelenül nagy lesz. Ahhoz, hogy ki tudjuk számolni a régiók többi régiótól való átlagos távolságát, azt feltételezzük, hogy ezen utak hossza egyenlő a hálózat szereplőinek számával, amely a hálózatelemzési szakirodalomban is a leggyakrabban használt módszer (West 1996). Ezt követően már könnyen kiszámolható az átlagos legrövidebb utak száma.

A régiók többi régiótól való átlagos távolságát szintén mind a tizenhat dimenzióban kiszámoljuk, majd ezt követően ezeket az értékeket összehasonlítjuk a következő speciális, domináns távolságmátrix alkalmazása mellett kapott értékekkel. Magnani és Rossi (2013) tanulmánya alapján abból indulunk ki, hogy a régiók különböző dimenziók mentén is kapcsolatban állhatnak egymással, azaz két régió eltérő távolságokra lehet egymástól a különböző dimenziókat vizsgálva. Ebben az esetben két régió közötti domináns távolság az alábbiak szerint írható fel:

$$
\bar{d}_{r, q}=\min _{f, g} d_{r, q}^{f, g}
$$

Két régió közötti domináns távolság az mutatja meg, hogy az egyik régió az összes intézménytípust figyelembe véve milyen (legrövidebb) távolságra van a többi régiótól a közvetlen kapcsolatok alapján. Hasonlóan a korábbi egyszerü távolságmátrixokhoz, ebben az esetben is kiszámolhatók a régiók közötti legrövidebb távolságok. Könnyen belátható, hogy a minimum értékek kiválasztása miatt ebben az esetben nem lehetnek nagyobbak az átlagos legrövidebb távolságok a különböző dimenziók szerint felírt esetek által kapott értékeknél.

Végül, a domináns távolságokon alapuló átlagos legrövidebb távolságokat összehasonlítjuk a tizenhat különböző dimenzió alapján kapott hasonló értékekkel, méghozzá oly módon, hogy előbbi értékét elosztjuk az utóbbiak értékével. A domináns távolságok meghatározása alapján (a minimum függvénynek köszönhetően) az így kapott arányszám maximális értéke 1, míg az ettől egyre kisebb értékek azt mutatják, hogy az adott dimenzió értékéhez képest az összes dimenzió figyelembevétele milyen mértékben javítja a régió információkhoz való hozzáférése.

A megértést szolgálja a következő egyszerü példa. Ha egy régió vállalatai szerteágazóan és intenzíven alakítottak ki kapcsolatokat a többi régió vállalataival, akkor e dimenzió szerint a régió átlagos legrövidebb távolsága is alacsony lesz. Továbbá, ha a régió az egyéb dimenziókban nem rendelkezik sok és sürü 
kapcsolati szerkezettel, akkor a régió domináns távolságainak meghatározása többnyire a régió vállalatai által, más régiók vállalataival kialakított kapcsolatai alapján történik. Ebben az esetben a domináns távolságok szerint számolt átlagos legrövidebb út értéke ugyan valamennyivel kisebb lesz, de közel akkora értéket fog felvenni, mint a kiinduló esetben, következésképpen a két távolság érték aránya is 1-hez közeli lesz. Ebben a példában tehát a régió az új tudást elsősorban a vállalatai által, más régió vállalataival kialakított kapcsolatainak köszönheti.

Az ebben a részben bemutatott távolság kapcsán hangsúlyozzuk, hogy az együttműködési hálózatban értelmezendő és bizonyos esetekben jelentősen különbözhet a földrajzi távolságoktól. Előfordulhat, hogy két régió a hálózati térben és a földrajzi térben is közel helyezkedik egymáshoz, viszont a bevezetőben bemutatott elemzések rámutatnak arra, hogy az együttmüködési kapcsolatoknak kiemelt szerepe van a tudásáramlásban, ami végső soron a hálózati és a földrajzi tér megkülönböztetését szorgalmazza.

\section{Empirikus eredmények}

A kutatási együttműködések alapján felrajzolt többrétegű hálózat szerkezeti elemzését az egyes dimenziók szerint meghatározott hálózatok általános tulajdonságainak ismertetésével kezdjük. Ezt követően a magyar megyék kapcsolatrendszerének bemutatása következik, ahol egyrészt megvizsgáljuk, hány együttmüködésben vettek részt az egyes magyar megyék, másrészt bemutatjuk, hogy milyen arányban létesítettek kapcsolatokat a vizsgált NUTS 3-as régióhoz képest. Végül az empirikus elemzés harmadik szakaszában azt vizsgáljuk meg, hogy a megyék tudásáramlásában milyen típusú kapcsolatok a meghatározóak.

Az eredményeket bemutató ábráknál az egyes dimenziók és megyék jelölésére rövidítéseket használunk. A vállalati kapcsolatokat $\mathrm{V}$, míg a felsőoktatási intézmények esetén $\mathrm{F}$, a kormányzati intézményeknél $\mathrm{K}$, a kutatóintézeteknél I jelöli. Ennek megfelelően például a VI dimenzió a vizsgált régió vállalatai által, más régiók kutatóintézeteivel kialakított kapcsolataira vonatkozik.

\section{A hálózatok általános tulajdonságai}

Ebben a fejezetben a hálózat általános tulajdonságai közül emelünk ki néhányat a 16 dimenzió mentén, rámutatva a többrétegü hálózatelemzés fontos szerepére. A különböző dimenziójú hálózatok általános jellemzői a függelék F1. táblázatában találhatók meg részletesen.

A hálózat mérete, azaz a vizsgált NUTS 3-as régiók száma 1 392, amely kiterjed az Európai Unió 27 tagállamára, az Egyesült Királyságra, Svájcra és Norvégiára. A régiók meghatározása a 2016-os lehatárolás alapján történt. 
3. ábra: A különböző intézménytípusok közötti élek aránya és a kapcsolatok sűrűsége The density of relationships and the distribution of edges between different institutions

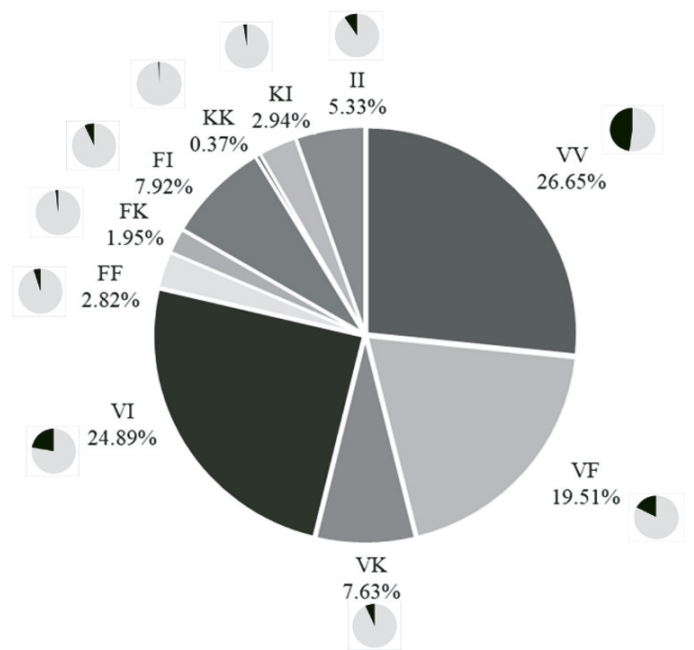

Forrás: saját szerkesztés

Megjegyzés: A vállalatokat $V$, a felsőoktatási intézményeket $F$, a kormányzati intézményeket $K$, a kutatóintézeteket pedig I jelöli. A rövidítések elsỏ betüje a vizsgált régióra vonatkozó intézménytípust jelzi, míg a második a többi régióra vonatkozva mutatja meg az intézmények típusát.

A 3. ábra megmutatja, hogy az 1392 vizsgált NUTS 3-as régiók közötti, összesen 1739547 kapcsolat milyen arányban van jelen az egyes intézménytípusok között. A diagram feliratai mellett a kisebb kördiagramok az adott részhálózat kapcsolatainak sűrűségét mutatják. Megállapíthatjuk, hogy a vállalatok közötti kapcsolatok száma a legmagasabb. A vállalatok és kutatóintézetek közötti kapcsolatok hasonlóan magas arányban vannak jelen, azonban sűrűségük jelentősen alacsonyabb a vállalatok közötti kapcsolatokhoz képest. A magas klaszterezettség is elsősorban a vállalatokra jellemzo, ez azt jelenti, hogy a régiókkal együttműködő „szomszédos” régiók közötti összekapcsoltság erős. A 16 részhálózat átlagos fokszáma és súlyozott fokszáma a kapcsolatok számához hasonlóan alakul, a súlyozott fokszám azonban jelentős mértékben magasabb a régiók vállalatai között. A vizsgált dimenziók fokszámeloszlása megmutatja a különböző kapcsolati számmal rendelkező csúcsok gyakoriságát. A legtöbb részhálózat esetében aszimmetrikus fokszámeloszlás figyelhető meg. A fokszámok pozitív ferdesége és a skálafüggetlen hatványkitevő is arra utal, hogy a legtöbb intézmény nagyjából ugyanannyi kapcsolattal rendelkezik, azonban néhány intézmény kiugróan magas együttmüködési kapcsolattal bír. ${ }^{1}$

A dolgozatban a korábban bemutatott módon, az 1999 és 2017 közötti együttműködési kapcsolatok éves átlagát vizsgáljuk meg a különböző dimenziók mentén. Az így kapott együttmúködési számosságok adják az elemzett tudáshálózat (súlyozott) kapcsolatait. A kapcsolatok szerkezetének dinamikus vizsgálata nem tárgya jelen tanulmánynak, azonban a bemutatott eredmények kapcsán ér- 
demes néhány tényezőt megemlíteni. Először is, a kapcsolatok száma az idő múlásával növekedett, hiszen a KP-ok is egyre nagyobb költségvetéssel rendelkeztek, továbbá az időszakban az Európai Unióhoz csatlakozó régiók szereplőinek is több lehetősége nyílt a programokban való részvételre. Másodszor, a régiók intézménytípusonkénti kapcsolatait elemezve az látható, hogy többé-kevésbé ugyanabba az intézményi típusba tartozó gazdasági szereplők alakították ki a kapcsolatokat a különböző időszakokban, és a legtöbb megye esetében stabilitás figyelhető meg ebben a tekintetben (lásd a függelék F2. táblázatát). Ezáltal a szük két évtizedet felölelő időszak egységként történő kezelése egyszerűbben teszi lehetővé a magyar megyék közötti különbségek feltárását az intézménytípusok szempontjából. Ettől függetlenül, a kapcsolatrendszer szerkezetének időbeli dinamikája is hasznos információkat szolgáltathat a tudásáramlással kapcsolatos korábbi vizsgálatokhoz képest, amit a jövőbeli kutatások során érdemes lehet alaposan megvizsgálni.

A legtöbb általunk vizsgált általános hálózatelméleti mutató esetében jelentős eltérések figyelhetők meg a 16 részhálózat tulajdonságaiban. A régiók együttműködési kapcsolatainak vizsgálata során tehát fontos az intézményi dimenzió figyelembevétele.

\section{A magyar megyék kapcsolatrendszere}

A magyar megyék kapcsolatrendszerének feltérképezése során először azt vizsgáljuk meg, hogy a vizsgált időszakban hány együttműködésben vettek részt, valamint, hogy mely intézménytípusok közötti kapcsolat a leggyakoribb. Fontos hangsúlyozni, hogy ebben az esetben a magyar megyék adatait az adott dimenzióban legtöbb kapcsolatot kialakított régió értékeivel normalizáltuk. Ennek köszönhetően az intézménytípusok szerepének vizsgálata független attól, hogy a KP-ok milyen típusú intézményeket részesítettek előnyben.

A 4. ábra mutatja az eredményeket, ahol minden oszlop egy megyét (NUTS 3 szintű régió, melyek kódolását a függelék F1 táblázata adja meg), míg minden sor egy kapcsolattípust jelenít meg. Az ábra a magyar megyéket vizsgáló korábbi szakirodalmakkal összhangban (például Lengyel 2003) a fóváros tudományos együttműködési szerepének fontosságát mutatja. A vizsgált Keretprogramok alatt (1999-2017) a legtöbb átlagos együttműködési kapcsolattal rendelkező Budapest (24 588,8) és Pest megye ( 9 694,5) mellett elsősorban azokban a megyékben figyelhetünk meg magas szintű együttműködést, amelyek nagyobb felsőoktatási intézményekkel rendelkeznek, például Hajdú-Bihar megye (4 621,8), Győr-MosonSopron megye (3 408,2) és Baranya megye (2 539,6). Az intézményi dimenziót vizsgálva megállapíthatjuk, hogy a magyar megyék vállalatai és felsőoktatási intézményei alakítják ki a legtöbb megye esetében az együttműködési kapcsolatokat. Kivételt képez azonban Budapest és Csongrád-Csanád megye, amelyek esetében a kutatóintézetek szerepe a legjelentősebb. Sőt, Budapest a hozzá tarto- 
4. ábra: A magyar megyék együttműködéseinek gyakorisága. The frequency of collaborations between Hungarian counties

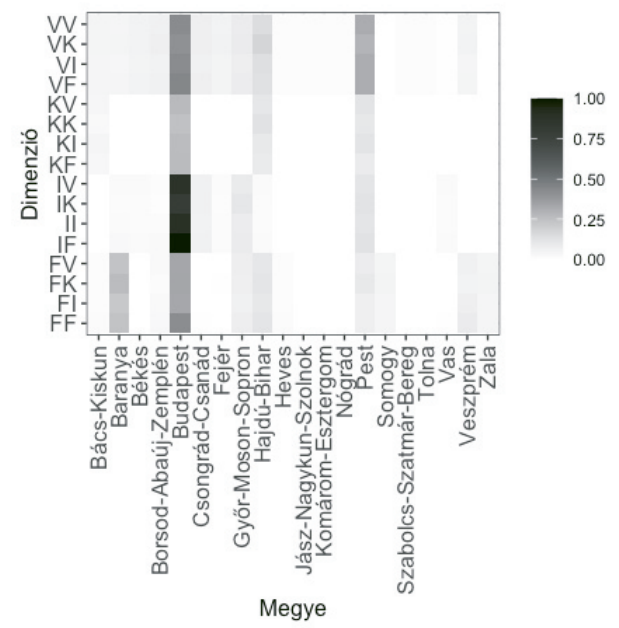

Forrás: saját szerkesztés

Megjegyzés: A vállalatokat $V$, a felsőoktatási intézményeket $F$, a kormányzati intézményeket $K$, a kutatóintézeteket pedig I jelöli. A röviditések első betüje a vizsgált régióra vonatkozó intézménytípust jelzi, míg a második a többi régióra vonatkozva mutatja meg az intézmények típusát.

zó kutatóintézetek által a más régiók felsőoktatási intézményeivel kialakított kapcsolatok számát tekintve az első helyen szerepel az összes európai régiót tekintve. A felsőoktatási intézmények által létrehozott kapcsolatokat nézve továbbá érdemes Baranya megyét is kiemelni, a fövárost követően ugyanis a második legtöbb kapcsolattal rendelkeznek. A vállalatok együttmüködési projektekben való részvételének vizsgálata során Budapest és Pest megye mellett Hajdú-Bihar megye kapcsolatainak száma jelentős. Végül, az eredmények rámutatnak arra, hogy jó néhány megye - mint például Komárom-Esztergom megye, Heves megye, Nógrád megye és Szabolcs-Szatmár-Bereg megye - egyetlen dimenzióban sem müködött kiemelkedően együtt más európai régiókkal.

A kapcsolatok gyakorisága mellett fontos megvizsgálni a régiók kapcsolati sűrűségét is (5. ábra), amely megmutatja, hogy a magyar megyék az összes vizsgált régió mekkora hányadával alakítottak ki együttmüködést. Amennyiben az összes potenciális kapcsolathoz viszonyítjuk a meglévő kapcsolatokat, láthatjuk, hogy Budapest már kevésbé emelkedik ki a magyar megyék közül. A budapesti felsőoktatási intézmények például a többi régió vállalataival létesített kapcsolatok alapján a régiók 68,2 százalékával alakítottak ki kapcsolatot, amelyhez képest Veszprém megye $(66,1 \%)$ és Győr-Moson-Sopron megye (65 \%) kapcsolati sürüsége is hasonló mértékủ az említett dimenzióban. Megállapíthatjuk tehát, hogy bár Budapest több keretprogramban vett részt, ezért súlyozott kapcsolatainak száma jelentősen meghaladja az országos átlagot, a sűrűséget vizsgálva arra következtethetünk, hogy ez nem a főváros szélesebb körű együttműködési hajlandóságá- 
5. ábra: A magyar megyék együttmüködéseinek sűrűsége.

The density of collaborations between Hungarian counties

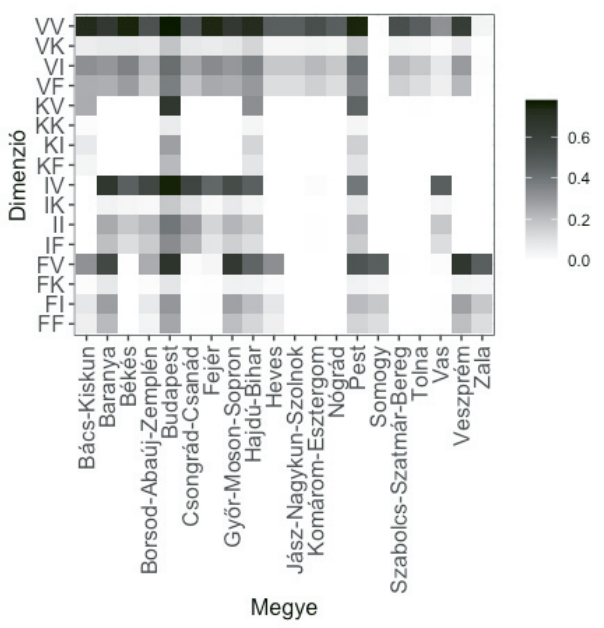

Forrás: saját szerkesztés

Megjegyzés: A vállalatokat $V$, a felsőoktatási intézményeket $F$, a kormányzati intézményeket $K$, a kutatóintézeteket pedig I jelöli. A röviditések első betüje a vizsgált régióra vonatkozó intézménytípust jelzi, míg a második a többi régióra vonatkozva mutatja meg az intézmények típusát.

nak, hanem a fővárosi intézmények partnerrégiókkal való intenzívebb együttmüködésének az eredménye.

A vállalatok különböző intézménytípusokkal kialakított együttmüködésének aránya általában kiegyensúlyozott, egyedül Zala és Somogy megye kapcsolati sürűsége alacsonyabb a magyar megyékhez képest. A kormányzati intézmények Budapest és Pest megye mellett Hajdú-Bihar megyében és Bács-Kiskun megyében alakítanak ki szélesebb körben együttmüködési kapcsolatokat, elsősorban a többi régió vállalataival, valamint kutatóintézeteivel. A kutatóintézetek sűrűsége Budapest és Pest megye mellett Fejér megyében, Győr-Moson-Sopron megyében, Baranya megyében, Borsod-Abaúj-Zemplén megyében, Hajdú-Bihar megyében, Békés megyében, Vas megyében és Csongrád-Csanád megyében a legmagasabb. Utóbbi három megye kivételével a felsorolt régiók felsőoktatási intézményei is széleskörüen vesznek részt a keretprogramok projektjeiben.

\section{Az intézménytípusok szerepe}

Az elemzésünk utolsó, harmadik részében azt mutatjuk be, hogy a magyar megyék esetében milyen típusú kapcsolatok járulnak hozzá a legnagyobb mértékben a tudás más régióktól való megszerzéséhez. Ahogy azt a módszertani részben is kifejtettük, ha két régió egy adott dimenzióban többször is együttműködött, akkor a tudásáramlás erős és a kapcsolatrendszer alapján értelmezett távolság rövid 
közöttük. Ebből kiindulva, egy régió átlagos legrövidebb távolsága megmutatja az összes többi régiótól származó hatékony tudásáramlás erősségét. Ezeket az átlagos legrövidebb távolságokat minden dimenzió esetében meghatározzuk. A következő lépésben megnéztük, hogy a régiók között mely dimenziókban a legszorosabb a kapcsolat erőssége, majd ezen kapcsolatokat kiválasztva létrehoztuk a domináns távolságmátrixot, amely alapján szintén kiszámoltuk a régiók legrövidebb átlagos távolságait. Végül, az így kapott értékeket összehasonlítva az egyes dimenziók mentén meghatározott értékekkel, megmutatjuk, hogy a régiók hatékony tudásszerzésében milyen típusú kapcsolatok játsszák a legfontosabb szerepet.

Az eredmények ismertetését először a domináns távolságmátrix alapján kiszámolt átlagos legrövidebb távolságokkal kezdjük. A korábbi eredményekkel összhangban - miszerint a legtöbb és legszerteágazóbb kapcsolatokkal Budapest rendelkezik - az átlagos legrövidebb távolsággal a fövárosi térség $(164,4695)$ rendelkezik, azaz a kapcsolatrendszert tekintve Budapest helyezkedik el a legközelebb a többi európai régióhoz. Hasonlóan alacsony értékkel rendelkezik Pest megye (164,4816), Hajdú-Bihar megye (164,5044), Fejér megye $(164,5631)$ és Veszprém megye $(164,5653)$ is. A magyar megyék közül a többi európai régiótól a legtávolabb Zala megye, Somogy megye, Heves megye, Nógrád megye és JászNagykun-Szolnok megye (valamennyi 164,8919 egységnyi távolságra) helyezkedik el a kialakított együttműködési kapcsolatrendszerben. Az átlagos legrövidebb távolságok vizsgálatával kapcsolatban fontos megemlíteni, hogy a hálózat óriáskomponensébe 1228 régió tartozik, ez azt jelenti, hogy a vizsgált régiók közül 1228 régió kapcsolódik össze egymással, ezáltal 164 régióhoz kizárólag a leghosszabb 1392 egységnyi útvonalon keresztül lehet eljutni.

A 6. ábra azt mutatja, hogy az egyes dimenziók mentén megfigyelt átlagos legrövidebb utak hogyan viszonyulnak a domináns távolságmátrixon alapuló számítás eredményeihez. Ha a két átlagos távolság értékének aránya közel esik 1hez, akkor az azt jelenti, hogy az adott dimenzió kapcsolatai nagyban hozzájárulnak a régió többi régiótól való tudásszerzéséhez. Ezzel ellentétben a 0-hoz közeli eredmények azt mutatják, hogy az adott dimenzió kapcsolatai kevésbé járulnak hozzá a tudás megszerzéséhez. Az ábrára pillantva két fontos eredmény látható. Egyrészt a magyar régiókhoz tartozó intézmények, legyen szó vállalatokról, felsőoktatási intézményekről, kormányzati intézményekről, vagy kutatóintézetekről, elsősorban a többi régió vállalataival kialakított kapcsolatokon keresztül kapcsolódnak a tudáshálózatokhoz, ezek a tudásszerzés elsődleges csatornái. Másrészt az egyes megyékben eltérő szereppel bírnak a régióhoz tartozó különböző intézménytípusok is. Somogy megyében például szinte kizárólag a felsőoktatási intézmények által kialakított kapcsolatoknak köszönhető a tudáshoz való hozzáférés, míg Jász-Nagykun-Szolnok megye esetében a vállalatoknak. A felsőoktatási intézmények szerepe azokban a megyékben (Komárom-Esztergom megye, Tolna megye, Nógrád megye és Jász-Nagykun Szolnok megye) alacsony, ahol nincs domináns egyetem vagy főiskola, ezáltal ezen régiók elsősorban a többi intéz- 
6. ábra: Az egyes dimenziók szerepe a tudáshoz való hozzáférésében.

The role of the different dimensions in accessing knowledge

Forrás: saját szerkesztés

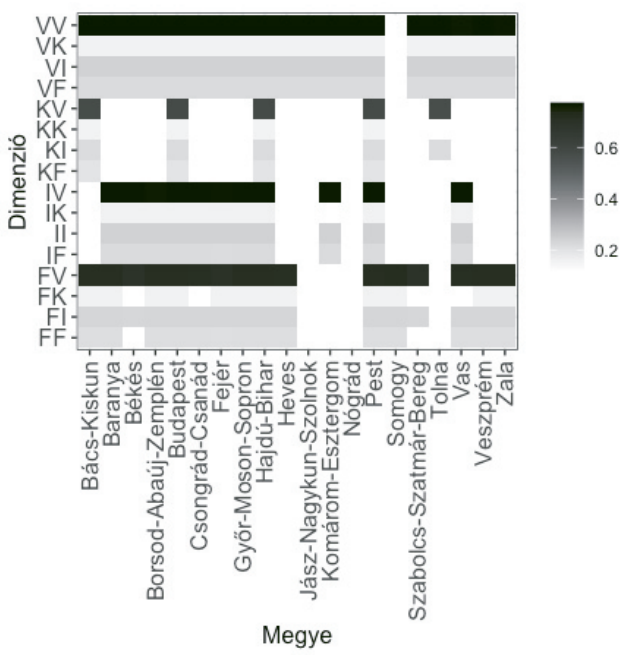

Megjegyzés: A vállalatokat $V$, a felsőoktatási intézményeket $F$, a kormányzati intézményeket $K$, a kutatóintézeteket pedig I jelöli. A rövidítések első betüje a vizsgált régióra vonatkozó intézménytípust jelzi, míg a második a többi régióra vonatkozva mutatja meg az intézmények típusát.

ménytípus által férnek hozzá a tudáshoz. Végül az eredményekről általánosságban az is elmondható, hogy a kormányzati intézetek és a kutatóintézetek szerepe kisebb a vállalatokhoz és a felsőoktatási intézményekhez képest, ezen intézménytípusok csak a megyék egy részében bírnak jelentős szereppel.

\section{Összefoglalás}

Tanulmányunkban azt mutattuk be, hogy a magyar megyék (NUTS 3 szintű régiók) az egyes intézménytípusok szerint milyen intenzív kapcsolatokat alakítottak ki a többi európai régióval az Európai Unió által finanszírozott KP-okban való együttmúködések alapján. Az intézmények közötti kutatói együttmúködések elemzése különösen fontos a régiók információhoz és tudáshoz való hozzáférésében, amely végső soron az innovációs tevékenység intenzitását is meghatározza.

Az eredmények összességében azt mutatják, hogy Budapest és Pest megye rendelkezik a legtöbb kialakított kapcsolattal, ráadásul ezeket a kapcsolatokat az európai régiók széles körében építették ki. A különböző kapcsolati dimenziók menti vizsgálatok azonban rámutatnak arra, hogy több megye (például Baranya megye és Hajdú-Bihar megye) elsősorban a felsőoktatási intézményei által kapcsolódott be a kutatói együttműködési projektekbe, míg más megyék (például Győr-Moson-Sopron megye és Csongrád-Csanád megye) alapvetően a kutatóintézetek által alakítottak ki kapcsolatokat. A kormányzati intézmények együttműkö- 
déseinek száma, a fővárost, Pest megyét, Hajdú-Bihar megyét és Bács-Kiskun megyét leszámítva, rendkívül alacsonynak mondható. A partneri kör szélességét tekintve az látható, hogy a fővároshoz képest több esetben is hasonlóan teljesítettek egyes megyék. A kutatóintézetek kapcsolatrendszerét tekintve Győr-Moson-Sopron megye és Csongrád-Csanád megye, a felsőoktatási intézmények esetében pedig Baranya megye rendelkezik hasonlóan széles körü partneri hálózattal. Végül, elemzésünk utolsó szakasza rámutat arra, hogy összességében a tudáshoz való hatékony hozzáférés szempontjából a magyar megyék különböző intézményeinek más régiók vállalataival kialakított kapcsolatai játszanak fontos szerepet.

A kapott eredményekből két fontos következtetés is levonható. Először is, jól látható, hogy az egyes intézménytípusok megyénként különböző szerepet játszanak az információszerzésben, megerősítve ezzel a szakirodalom korábbi állításait (Maietta 2015; Reichert 2019; Schaeffer et al. 2018). Veszprém megyében és Borsod-Abaúj-Zemplén megyében a vállalatok játszanak kiemelkedő szerepet, míg Baranya megyében a felsőoktatási intézmények, Csongrád-Csanád megyében a kutatóintézetek, Bács-Kiskun megyében pedig a kormányzati intézmények a legfontosabb csatornái a régión kívüli tudáshoz való hozzáférésnek. Másodszor fontos azt is észrevenni, hogy Tolna megye, Heves megye, Nógrád megye, Jász-Nagykun-Szolnok megye és Szabolcs-Szatmár Bereg megye esetében kevésbé sikerült intenzív kapcsolatokat kialakítani. Ezáltal ezek a régiók kisebb mértékben férnek hozzá tudáshoz, ami végső soron az innovációs tevékenységüket is korlátozza (Reillon 2017; Varga, Sebestyén 2015). Bár a dolgozatnak közvetlen fókuszában nem állt, az eredmények rávilágítanak a közszféra (felsőoktatás, kutatóintézetek, kormányzati intézmények) és a magánszféra (vállalatok) közötti kapcsolatok szerepére is. Azt látjuk, hogy ezek a fajta kapcsolatok, bár nem a legerősebbek, jelen vannak és sok esetben egészen jelentős tényezői egy-egy megye kutatási kapcsolatrendszerének. Fontos ugyanakkor azt is látni, hogy nagyon eltérő eredményt kapunk akkor, amikor a megyék vállalatainak külső kapcsolatait vizsgáljuk egyetemekkel, kutatóintézetekkel vagy kormányzati szereplőkkel, mint amikor a közszféra külső kapcsolatait nézzük vállalatokkal. Utóbbi dimenzió mentén magasabb értékeket látunk, aminek az az oka, hogy a sokszereplős együttműködési projektekben a hazai közszféra szereplői nagyobb valószínűséggel kerülnek kapcsolatba vállalati partnerekkel a külföldi résztvevőkön keresztül, mint ahogy a hazai vállalatok alakítanak ki hasonló kapcsolatokat.

A kapott eredmények kiértékelésével kapcsolatban fontos megjegyezni, hogy a felhasznált adatbázisban található együttműködéseket különböző alprogramok finanszírozzák, amelyek eltérő mértékben részesítik előnyben az egyes intézménytípusokat (Kosztyán, Csányi, Kurbucz 2019). Ebből kifolyólag az általunk feltárt különbségek egy része ebből a torzításból is fakadhat. Lényeges azonban az a megállapítás is, hogy az egyes intézménytípusok eltérő szerepet töltenek be a különböző megyékben. Például a kutatóintézetek a tudásáramlás szempontjából 
fontosak Bács-Kiskun és Tolna megyében, míg a felsőoktatási intézmények szerepe alacsony. Ezzel szemben Békés és Fejér megyében éppen fordított helyzet. A kapcsolatok számával összefüggő elemzések az adott dimenzióban legtöbb kapcsolattal rendelkező régióhoz viszonyítva kerültek feltüntetésre, ahol szintén jelentős különbségek alakultak ki a megyék között az egyes intézménytípusok esetében. Ezek az eredmények összességében azt mutatják, hogy a megyék között feltárt eltérések nem az egyes programok preferált intézményi körei miatt alakultak ki.

Ezzel együtt fontos lehet a továbbiakban részprogramonként, tematikus területenként elemezni az együttműködési hálózatokat, ahogyan részletesebb időbeli analízist is elvégezni. Ezen felül a megyék külső kapcsolatait érdemes lehet földrajzilag elkülönítetten kezelni, így további fontos következtetések vonhatók le a megyék beágyazottságára vonatkozóan az egyes dimenziók mentén.

\section{Jegyzet}

1 Egy komplex hálózat Barabási és Albert (1999) tanulmánya szerint skálafüggetlen, ha a fokszámeloszlás hatványfüggvény eloszlást követ: $P(k) \sim k^{-\gamma}$, ahol $2 \leq \gamma \leq 3$.

\section{Köszönetnyilvánítás}

Jelen publikáció az Európai Unió, Magyarország és az Európai Szociális Alap társfinanszírozása által biztosított forrásból, az EFOP-3.6.2-16-2017-00017 azonosítójú „Fenntartható, intelligens és befogadó regionális és városi modellek" című projekt keretében született.

\section{Irodalom}

Ács, J. Z., Stam, E., Audretsch, D. B., O'Connor, A. (2017): The lineages of the entrepreneurial ecosystem approach. Small Business Economics, 49., 1-10. https://doi.org/gdrb5r

Aghion, P., Howitt, P. (1992): A model of growth through creative destruction. Econometrica, 2., 323-351. https://doi.org/c86jmr

Akçomak, S., Erdil, E., Çetinkaya, U. Y. (2018): Knowledge Convergence in European Regions: Towards Cohesion? MERIT Working Papers 027. Maastricht Economic and social Research Institute on Innovation and Technology - Maastricht Graduate School of Governance, Maastricht

Alvedalen, J., Boschma, R. (2017): A critical review of entrepreneurial ecosystems research: towards a future research agenda. European Planning Studies, 6., 887-903. https://doi.org/f94b87

Anselin, L. Varga, A., Ács, Z. (1997): Local geographic spillovers between university research and high technology innovations. Journal of Urban Economics, 3., 422-448. https://doi.org/bcdgmq

Barabási, A. L., Albert, R. (1999): Emergence of scaling in random networks. Science, 286(5439), 509-512. https://doi.org/ccsmnz

Becker, W., Dietz, J. (2004): R\&D cooperation and innovation activities of firms - evidence for the German manufacturing industry. Research Policy, 2., 209-223. https://doi.org/d86xhn 
Boccaletti, S., Bianconi, G., Criado, R., Del Genio, C. I., Gómez-Gardenes, J., Romance, M., Zanin, M. (2014): The structure and dynamics of multilayer networks. Physics Reports, 544 (1), 1-122. https://doi.org/vhg

Boschma, R. A. (2005): Proximity and innovation: A critical assessment. Regional Studies, 1., 61-74. https://doi.org/dbmh2k

Boschma, R. A., ter Wal, A. L. J. (2007): Knowledge networks and innovative performance in an industrial district: The case of a footwear district in the south of Italy. Industry and Innovation, 2., 177-199. https://doi.org/cdnc23

Breschi, S., Lissoni, F. (2003): Mobility and social networks: localised knowledge spillovers revisited. CESPRI, Working Paper 142.

Breschi, S., Lenzi, C. (2016): Co-invention networks and inventive productivity in US cities. Journal of Urban Economics, 3., 66-75. https://doi.org/f8jgbc

Broekel, T., Meder, A. (2008): The bright and dark side of cooperation for regional innovation performance. Jena Economic Research Papers, 053. Friedrich Schiller University Jena and Max Planck Institute of Economics, Jena

Broekel, T., Brenner, T., Buerger, M. (2015): An investigation of the relation between cooperation intensity and the innovative success of German regions. Spatial Economic Analysis, 1., 52-78. https://doi.org/gqmm

Csáfordi, Z., Lőrincz, L., Lengyel, B. Kiss, K. M. (2018): Productivity spillovers through labor flows: productivity gap, multinational experience and industry relatedness. The Journal of Technology Transfer, 1., 86-121. https://doi.org/gqmn

D’Ambrosio, A., Montresor, S., Parrilli, M. D., Quatraro, F. (2019): Migration, communities on the move and international innovation networks: An empirical analysis of Spanish regions. Regional Studies, 1., 6-16. https://doi.org/gqmq

Dijkstra, E. W. (1959): A note on two problems in connexion with graphs. Numerische Mathematik, 1. , 269-271. https://doi.org/dpvk8c

Feldman, M. P. (1994): The Geography of Innovation. Kluwer Academic Publisher, Boston https:// doi.org/gqms

Fitjar, R. D., Rodríguez-Pose, A. (2020): Where cities fail to triumph: The impact of urban location and local collaboration on innovation in Norway. Regional Science, 1., 5-32. https://doi.org/gqmx

Fritsch, M., Slavtchev, V. (2010): How does industry specialization affect the efficiency of regional innovation systems? The Annals of Regional Science, 1., 87-108. https://doi.org/c8bvgf

Grossman, G. M., Helpman, E. (1994): Endogenous Innovation in the Theory of Growth. Journal of Economic Perpectives, 8., 23-44. https://doi.org/cbcrxp

Hau O., Sebestyén T., Varga A. (2016): Tudáshálózatok szerepe a regionális fejlődésben - egy integrált modell alkalmazásának tapasztalatai a magyar régiók esetében. Statisztika Szemle, 2., 117-142.

Henderson, V. (1997): Medium size cities. Regional Science and Urban Economics, 6., 583-612. https:// doi.org/bjbhrg

Interdonato, R., Magnani, M., Perna, D., Tagarelli, A., Vega, D. (2020): Multilayer network simplification: approaches, models and methods. Computer Science Review, 36, 100246. https://doi.org/gjfh66

Jacobs, J. (1969): The economy of cities. Vintage, New York

Jaffe, A. B. (1989): Real effects of academic research. American Economic Review, 5., 957-970.

Kosztyán Zs. T., Csányi V. V., Kurbucz M. T. (2019): A Hetedik Keretprogram többszintü, dinamikus hálózati elemzése. Statisztika Szemle, 2., 111-145. https://doi.org/gqm2

Lengyel I. (2003): Verseny és területi fejlődés: Térségek versenyképessége Magyarországon. JATEPress, Szeged Lobo, J., Strumsky, D. (2008): Metropolitan Patenting, Inventor Agglomeration and Social Networks. A Tale of Two Effects. Journal of Urban Economics, 3., 871-884. https://doi.org/c3v7xj

Lundvall, B. A. (ed.) (2010): National systems of innovation: Towards a theory of innovation and interactive learning. (Vol. 2.) Anthem Press, London

Magnani, M., Rossi, L. (2013): Pareto distance for multi-layer network analysis. In: Greenberg, A.M., Kennedy, W.G., Bos, N.D. (eds.): Social Computing, Behavioral-Cultural Modeling and Prediction. SBP 2013. Lecture Notes in Computer Science, 7812. Springer, Berlin, Heidelberg https://doi.org/f24htg 
Maietta, O.W. (2015): Determinants of university-firm R\&D collaboration and its impact on innovation: A perspective from a low-tech industry. Research Policy, 7., 1341-1359. https://doi.org/f7h3ht

Marshall, A. (1961): Principles of Economics. An Introductory Volume. MacMillan and Co. Ltd., London

Porter, M. A. (2018): What is... a Multilayer Network. Notices of the AMS, 65(11). https://doi.org/gqm3

Reichert, S. (2019): The Role of Universities in Regional Innovation Ecosystems. European University Association https://www.eua.eu/downloads/publications/eua\%20innovation\%20ecosytem\%20 report\%202019-3-12.pdf (Letöltés: 2021. 04. 22.)

Reillon, V. (2017): EU framework programmes for research and innovation: Evolution and key data from FP1 to Horizon 2020 in view of FP9. European Parliamentary Research Service https://www.europarl.europa.eu/thinktank/en/document.html?reference=EPRS_IDA(2017)608697 (Letöltés: 2021. 04. 22.)

Romer, P. (1990): Endogenous Technological Change. Journal of Political Economy, 5., S71-S102. https:// doi.org/c3tb4t

Santoalha, A. (2018): Technological diversification and Smart Specialisation: The role of cooperation. Regional Studies, 9., 1269-1283. https://doi.org/gqm4

Schaeffer, P.R., Fischer, B., Queiroz, S. (2018): Beyond education: The role of research universities in innovation ecosystems. Foresight and STI Governance, 2., 50-61. https://doi.org/ghrnvq

Sebestyén T. (2011): Hálózatelemzés a tudástranszferek vizsgálatában - a régiók közötti tudáshálózatok struktúrájának alakulása Európában. Statisztika Szemle, 6., 667-697.

Sebestyén T. (2012): Régiók hálózata és gazdasági teljesítmény. A régiók közötti tudáshálózati struktúra makrogazdasági szerepének vizsgálata. Tér és Társadalom, 3., 69-92. https://doi.org/gqm5

Sebestyén, T., Braun, E., Iloskics, Z., Varga, A. (2021): Spatial and institutional dimensions of research collaboration: A multidimensional profiling of European regions. Regional Statistics, 11., 3-31. https://doi.org/10.15196/RS110203

Sebestyén, T., Varga, A. (2013): Research productivity and the quality of interregional knowledge networks. The Annals of Regional Science, 1., 155-189. https://doi.org/f43dqz

Solow, R. M. (1957): Technical Change and the Aggregate Production Function. Review of Economics and Statistics, 3., 312-320. https://doi.org/d3hn2v

Varga A., Sebestyén T. (2015): Innováció Kelet-Közép Európában. Közgazdasági Szemle, 9., 881-908. https://doi.org/gqm6

West, D.B. (1996): Introduction to Graph Theory. Upper Saddle River, N.J.: Prentice Hall 


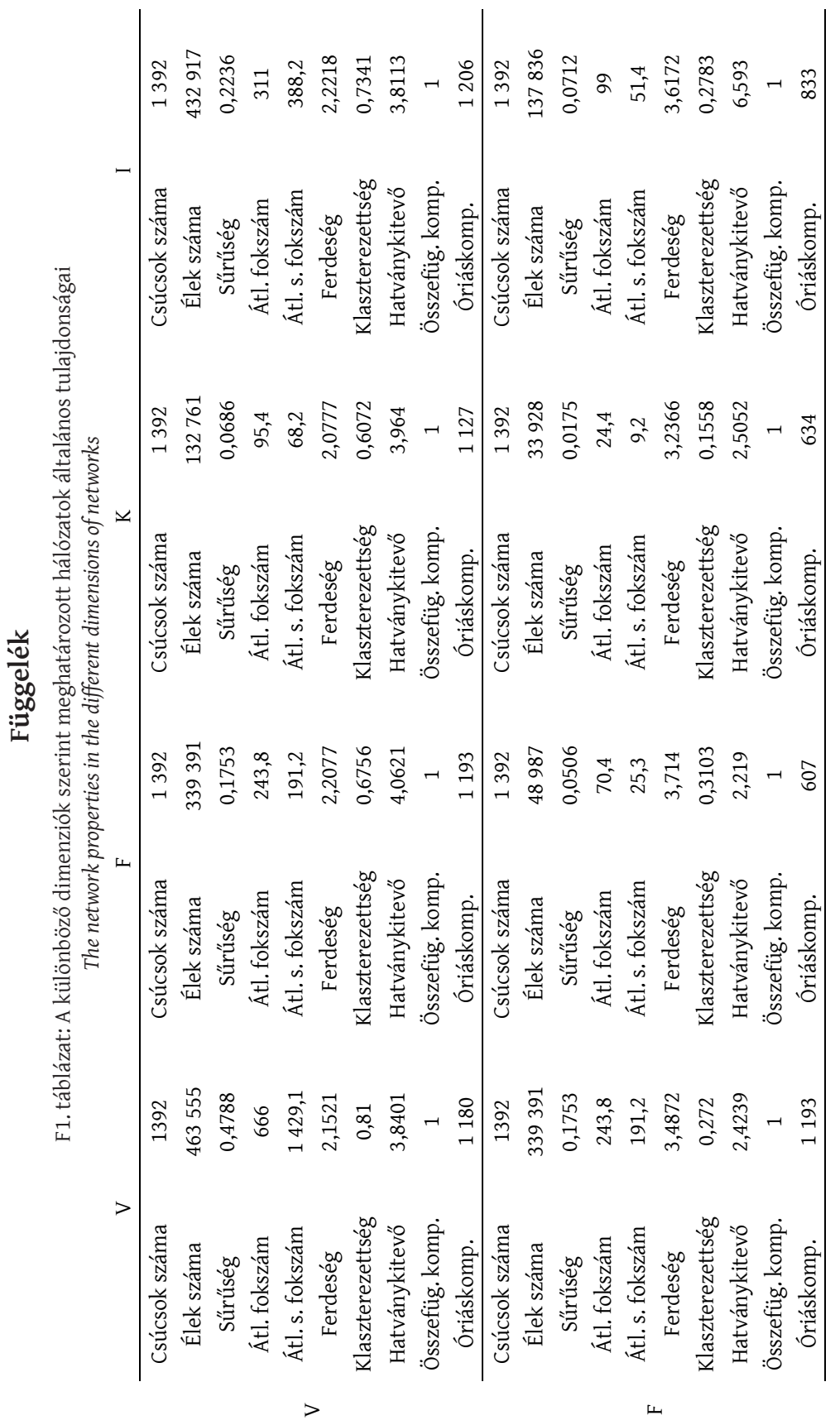




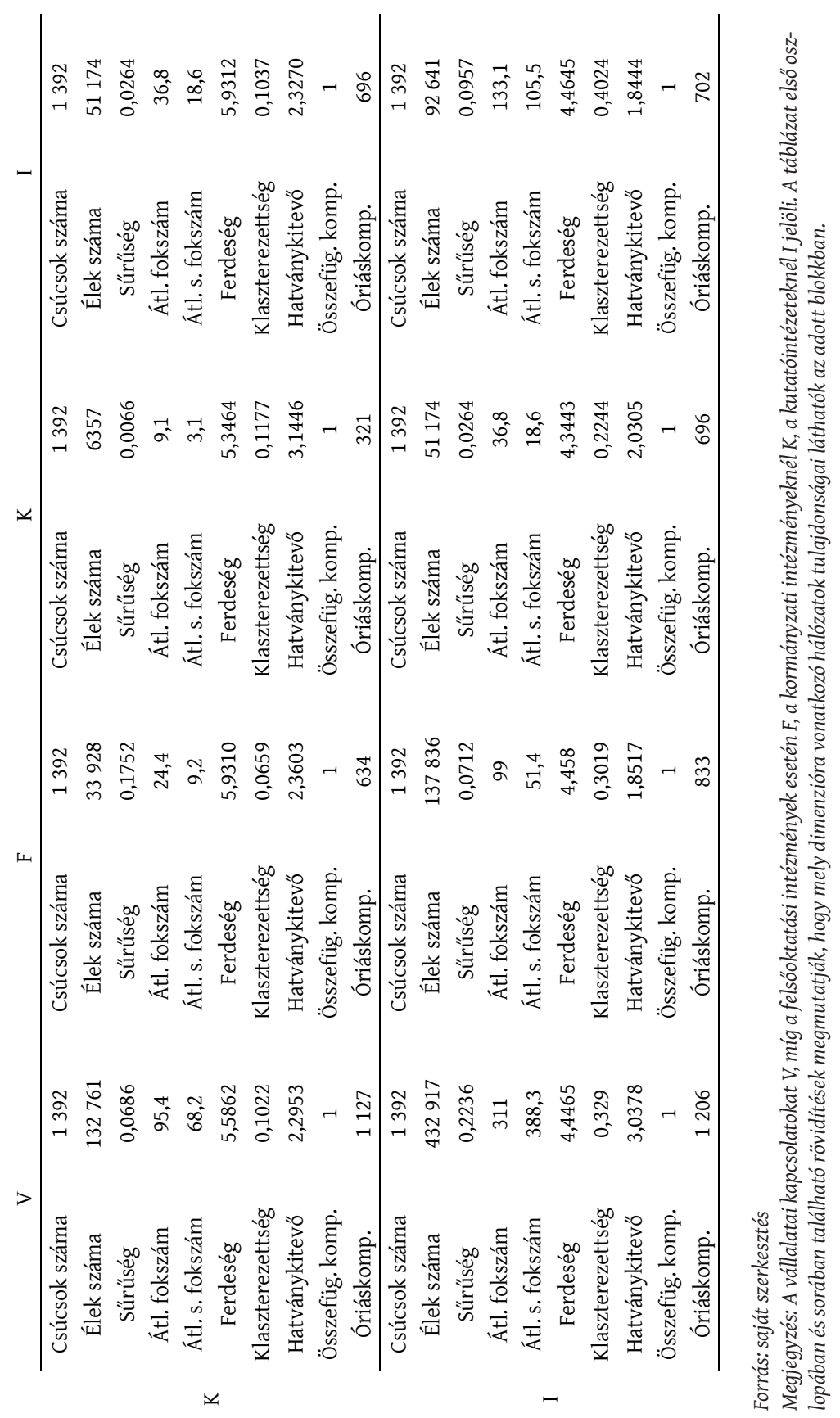




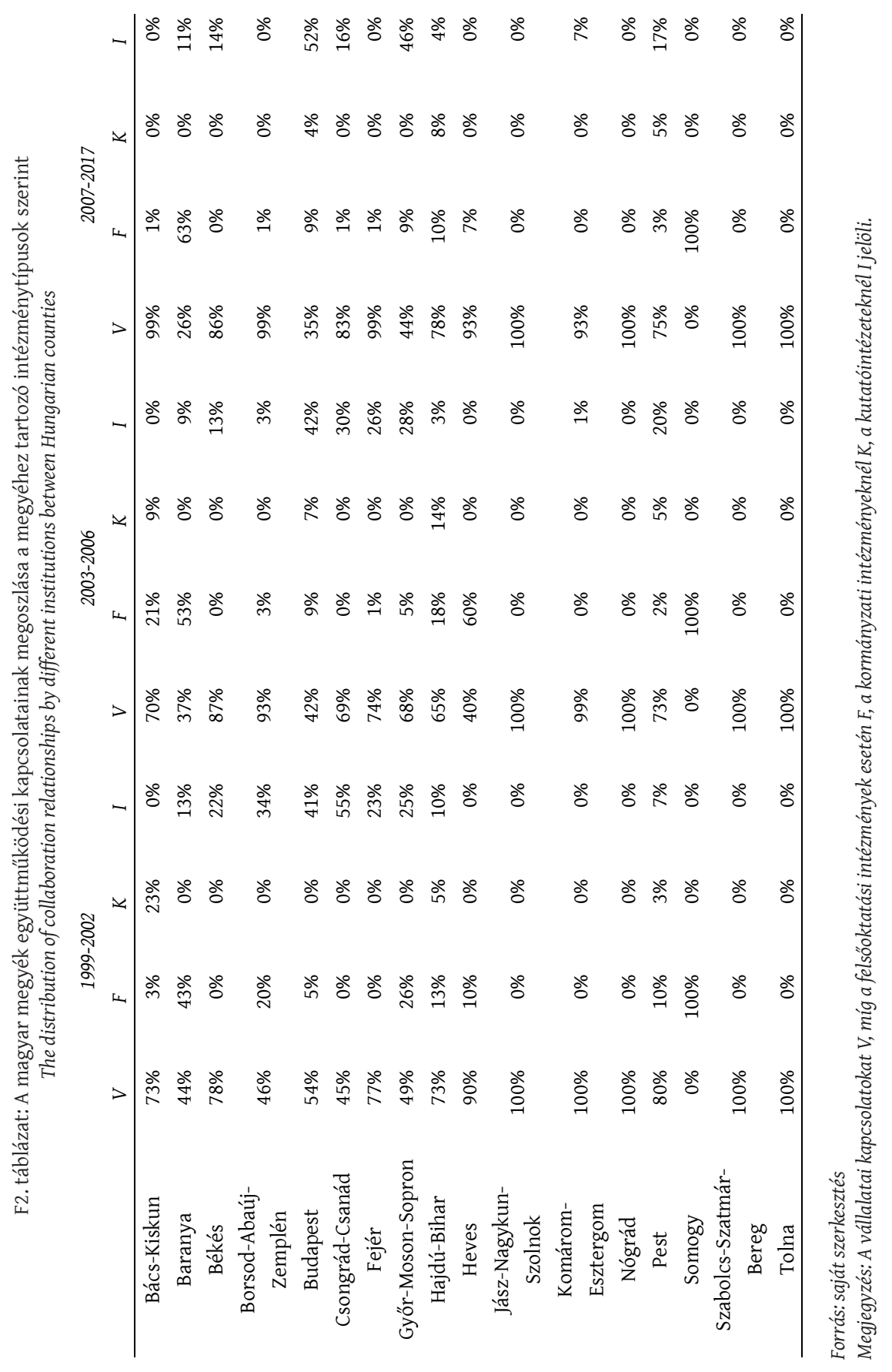

